\title{
MANFAAT AIR MINUM BAGI KESEHATAN PESERTA DIDIK PADA TINGKAT MI/SD
}

\author{
Nadya Prameski Putri ${ }^{1}$ dan Anis Fuadah $Z^{2}$ \\ 1,2 Pendidikan Guru Madrasah Ibtidaiyah,Universitas Islam Negeri Syarif Hidayatullah Jakarta \\ Email : nadya.prameski19@mhs.uinjkt.ac.id ${ }^{1}$, anisfuadah.zuhri@uinjkt.ac.id $^{2}$
}

Website:

https://jurnal.uinantasari.ac.id/index.php/adzka

Received: 13 Mei 2020; Accepted: 9 Juni 2020; Published: 9 Juni 2020

\begin{abstract}
Drinking water is one of the most important things in human life, especially in the health sector. Without drinking water regularly, human body will become dehydrated. Not only that, human body can also be easily attacked by other diseases caused by lack of fluids in the body. The purpose of this study was to analyze the importance of the benefits of drinking water for children in elementary school. The method used in this study is the method of library study where the writer will search for and read literary sources that have a relationship with drinking water. The results of this study state that there are many benefits from consuming drinking water, especially for the health of children in elementary school, children in this age tend to be more active, so that more fluids in the body will be excreted. Therefore, parents and educators should persuade their children to drinking water regularly so that the body does not lose fluids and avoid disease.
\end{abstract}

Key Words : drinking water; elementary school; health.

\begin{abstract}
ABSTRAK
Air Minum merupakan salah satu hal yang paling penting dalam kehidupan manusia, terutama di bidang kesehatan. Tanpa meminum air secara teratur, tubuh manusia akan mengalami dehidrasi. Tidak hanya itu, tubuh manusia juga dapat dengan mudah diserang oleh penyakitpenyakit lainnya yang disebabkan oleh kekurangan cairan dalam tubuh. Tujuan penelitian ini adalah untuk menganalisa seberapa penting manfaat air minum bagi manusia terutama pada anak-anak tingkat pendidikan MI/SD. Metode yang digunakan dalam penelitian ini adalah metode studi pustaka dimana penulis akan mempelajari dan membaca sumber-sumber literatur yang memiliki keterkaitan dengan air minum. Hasil penelitian ini menyatakan bahwa terdapat banyak sekali manfaat dari mengkonsumsi air minum terutama bagi kesehatan anak-anak pada tingkat MI/SD, karena anak-anak pada usia ini cenderung lebih bergerak aktif, sehinga cairan yang ada dalam tubuh akan lebih banyak dikeluarkan. Oleh karena itu, orangtua dan pendidik haruslah mengajak anak-anaknya untuk mengkonsumsi air minum secara teratur agar tubuh tidak kehilangan cairan dan terhindar dari penyakit.
\end{abstract}

Kata Kunci : air minum; MI/SD; kesehatan.

\section{PENDAHULUAN}

Air merupakan salah satu unsur yang sangat penting bagi sebuah kehidupan, karena tanpa adanya air maka tidak akan ada kehidupan di muka bumi. Hal tersebut dapat terjadi karena semua makhluk hidup pada umumnya lebih membutuhkan air untuk melaksanakan kegiatannya. Oleh karena itu air menjadi komponen yang paling penting dalam kehidupan sehari-hari. Hampir 71\% permukaan di bumi merupakan perairan (Dewi Hastuti et al., 2015). Hal ini menandakan bahwa di bumi ada kehidupan bagi makhluk hidup dimana semuanya sangat bergantung terhadap air untuk melakukan kegiatannya. 
Manusia dapat memanfaatkan air untuk berbagai macam kegiatan seperti mencuci, memasak, mandi, minum, dan lain sebagainya. Selain manusia, hewan dan tumbuhan juga memerlukan air untuk menjaga kelangsungan hidupnya seperti, tumbuhan yang memerlukan air untuk melarutkan zat hara dan membantu proses fotosintesis, sedangkan hewan memerlukan air untuk minum. Selain itu, air juga berperan penting bagi kesehatan manusia, karena pada umumnya $70-80 \%$ bagian yang ada di dalam tubuh manusia berbentuk cairan (Sari, 2014). Air mengandung zat gizi yang dapat membantu melarutkan berbagai macam zat kimia dalam tubuh, sehingga manusia sangat diwajibkan untuk mengkonsumsi air minum secara teratur. Namun pada kenyataannya, manusia sering kali melupakan peranan air bagi kesehatan. Hal ini dapat terjadi dikarenakan adanya berbagai macam kesibukan yang berbedabeda dari setiap orang, sehingga banyak yang lupa untuk mengkonsumsi air minum secara teratur.

Dalam kegiatan sehari-hari manusia memerlukan energi dari makanan dan minuman untuk mempertahankan kelangsungan hidupnya. Manusia tidak mampu bertahan tanpa minum, karena pada umumnya $70-80 \%$ dari tubuh manusia terdiri dari air, terutama otak dan darah, sehingga manusia tidak bisa hidup tanpa adanya air (Maulana, 2018). Pemahaman ini sering kali tidak diketahui oleh setiap orang, sehingga kesalahan yang sering terjadi adalah kebiasaan mengkonsumsi air minum hanya ketika haus saja. Hal ini mengakibatkan pengeluaran dan pemasukan air yang terjadi pada tubuh manusia tidak seimbang. Kejadian inilah yang nantinya mampu menyebabkan seseorang mengalami dehidrasi. Dehidrasi merupakan sebuah gejala dimana seseorang mengalami kekurangan air atau cairan dalam tubuhnya yang diakibatkan dari ketidakseimbangan antara pengeluaran dan pemasukan air dalam tubuh.

Selain dehidrasi, adapula dampak lain dari kurangnya mengkonsumsi air minum yaitu, timbulnya berbagai macam penyakit seperti, batu ginjal, diabetes, obesitas, serta gangguan pencernaan dan fungsi jantung. Kekurangan cairan tersebut dapat terjadi disebabkan manusia tidak hanya mengeluarkan cairan melalui keringat. Manusia juga dapat mengeluarkan cairan melalui pernapasan dan urin, sehingga apabila tidak ada cairan yang masuk untuk menggantikan cairan yang keluar, maka tubuh akan mengalami dehidrasi dikarenakan pengeluaran dan pemasukan cairan dalam tubuh tidak seimbang. Agar cairan dalam tubuh bisa kembali normal, maka manusia diwajibkan untuk mengkonsumsi air minum secara teratur, terutama air putih atau yang biasa disebut dengan air mineral.

Namun di era ini, air putih tidak lagi menjadi minuman prioritas bagi beberapa kalangan baik anak-anak, remaja, maupun orang dewasa (Ranteallo, 2015). Hal ini disebabkan adanya berbagai macam minuman baru yang mengikuti trend zaman, sehingga mereka lebih terbiasa mengkonsumsi minuman tersebut dibandingkan mengkonsumsi air putih (Ranteallo, 2015). Selain itu, kurangnya sosialisasi atau pengetahuan terkait dengan pentingnya air putih bagi kesehatan (Ranteallo, 2015) juga mampu memberikan mereka peluang untuk bersikap acuh dalam memperhatikan kesehatan dan kebutuhan air pada tubuh manusia. Oleh karena itu, orangtua dan guru sangat berperan penting untuk memberikan pengetahuan atau pembelajaran terkait fungsi air minum bagi kesehatan anak atau peserta didiknya. Guru maupun orangtua harus mampu memberikan penerapan atau contoh yang baik dan benar kepada peserta didik khususnya pada tingkat MI/SD terkait dengan mengkonsumsi air minum secara teratur supaya generasi muda saat ini tidak lagi mengabaikan fungsi air minum bagi kesehatan.

Tujuan dari penelitian ini adalah untuk menyusun dan mendeskripsikan manfaat, syaratsyarat, dan aturan dalam mengkonsumsi air minum bagi kehidupan makhluk hidup, terutama manusia dalam bidang kesehatan dan mendeskripsikan cara guru maupun orangtua untuk memperkenalkan manfaat air minum kepada peserta didiknya terutama pada tingkat MI/SD melalui pendidikan karakter dalam Kurikulum 2013 baik di lingkungan sekolah maupun di rumah. 


\section{METODE PENELITIAN}

Dalam penelitian ini, penulis menggunakan metode penelitian studi pustaka (Library Research). Studi pustaka dapat diartikan sebagai rangkaian kegiatan yang berkenaan dengan metode pengumpulan data pustaka dengan cara membaca, mencatatat, serta mengolah bahan penelitian (Supriyadi, 2016). Subjek objek dalam penelitian ini ialah anak-anak yang pada umumnya masih dalam tingkat pendidikan dasar. Sumber bacaan dalam studi pustaka terbagi kedalam 2 hal, yaitu sumber bacaan umum berupa buku-buku teks, ensiklopedia, monograp, dan sejenisnya, serta sumber bacaan khusus berupa jurnal, bulletin penelitian, tesis, dan lainlain (Harahap, 2014). Dalam penelitian ini, penulis menggunakan sumber data yang berasal dari sumber bacaan khusus seperti jurnal, artikel, tesis, dan lain sebagainya yang memiliki keterkaitan dengan permasalahan yang ada.

Teknik pengumpulan data yang dilakukan oleh penulis ialah dokumentasi dan teknik simak. Teknik dokumentasi, yaitu mencari data mengenai hal-hal atau variabel yang berupa catatan, buku, makalah, atau artikel, jurnal dan sebagainya (Mirzaqon \& Purwoko, 2017), sedangkan teknik simak berarti penulis mengumpulkan beberapa bahan literatur untuk dicatat atau dikutip pendapat para ahli yang ada dalam sumber bacaan tersebut yang isinya terkait dengan penelitian yang sedang penulis lakukan. Instrumen penelitian yang digunakan oleh penulis berupa referensi dan catatan penulis dari beberapa jurnal, tesis, potongan makalah, dan sumber lainnya yang memiliki keterkaitan dengan masalah yang ada pada artikel ini. Teknik analisis data yang digunakan oleh penulis adalah teknik analisis isi yang berfokus pada isi dimana peneliti akan lebih fokus untuk menganalisis dan membandingkan sumber-sumber yang ada, sehingga kekekalan proses pengkajian dapat terjaga dan mencegah terjadinya misinformasi (Putri, 2019).

\section{HASIL DAN PEMBAHASAN}

Penelitian ini bertujuan untuk memberitahukan pentingnya mengkonsumsi air minum secara teratur di bidang kesehatan, terutama bagi anak-anak pada tingkat pendidikan sekolah dasar. Pada era ini manusia seringkali melupakan pentingnya mengkonsumsi air minum, terutama air putih dikarenakan kesibukan sehari-hari dan adanya berbagai jenis minuman baru yang mengikuti trend zaman. Hal tersebutlah yang mampu memberikan dampak negatif bagi tubuh manusia, sehingga timbul berbagai macam penyakit yang menyerang tubuh seperti, kerusakan ginjal, kencing batu, dan lain-lain. Dari hasil penelitian dapat diketahui bahwa peranan orangtua dan pendidik sangatlah penting untuk memberikan pendidikan dan contoh yang baik terkait dengan pentingnya mengkonsumsi air minum bagi kesehatan. Hal tersebut harus di lakukan agar generasi muda saat ini tidak lagi mengabaikan pentingnya air minum bagi kesehatan diri masing-masing.

Berikut ini merupakan beberapa pembahasan terkait dengan hasil penelitian, diataranya :

\section{A. Air Minum}

Air merupakan salah satu kebutuhan vital bagi manusia sehingga fungsinya tidak dapat digantikan oleh senyawa lain terutama sebagai air minum. Hal ini menjadi sangat penting dikarenakan tubuh manusia sangat memerlukan air. Hampir 70-80\% tubuh manusia membutuhkan air dan mengandung air. Apabila tubuh kekurangan air, maka manusia akan mengalami dehidrasi. Maka dari itu sangatlah dianjurkan bagi manusia untuk mengkonsumsi air minum terutama air putih secara teratur.

Air minum adalah air yang kualitasnya memenuhi syarat kesehatan dan dapat langsung diminum, syarat kesehatan yang dimaksud adalah mikrobiologi, kimia, fisika, dan radioaktif (Mirza, 2014). Sesuai dengan Peraturan Menteri Kesehatan No. 492/Menkes/Per/IV/2010 tentang persyaratan air minum, ialah tidak berwarna, tidak berbau, tidak berasa, tidak 
mengandung mikroorganisme yang dapat membahayakan tubuh, dan tidak mengandung logam berat. Dalam peraturan tersebut salah satunya menyebutkan bahwa dalam air minum tidak boleh mengandung coliform (Mirza, 2014).

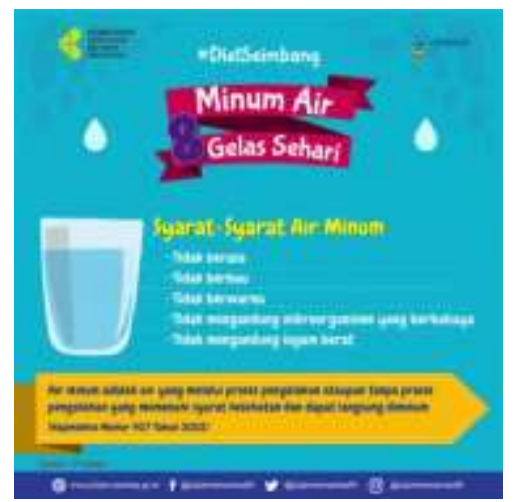

Gambar 1. Syarat-syarat air minum.

Sumber : Sites.google. Diakses melalui http://www.p2ptm.kemkes.go.id/infographicp2ptm/hipertensi-penyakit-jantung-dan-pembuluh-darah/apa-saja-syarat-syarat-air-minum

Air berasal dari berbagai sumber dan tempat yang berbeda-beda, sehingga warna airnya pun sudah pasti berbeda-beda. Salah satu syarat yang harus dipenuhi agar air dapat dikonsumsi ialah tidak berwarna. Air yang berwarna atau keruh biasanya mengandung ion besi, mangan, humus, biota laut, plankton, dan ilmiah industri lainnya. Air yang mengandung hal-hal tersebut tidak baik untuk dikonsumsi manusia (Yulianti, 2015). Oleh karena itu, air harus jernih atau bersih agar dapat dikonsumsi manusia. Selain itu, air yang dapat dikonsumsi manusia tidak boleh berbau. Air yang memiliki bau menandakan bahwa air tersebut sudah terkontaminasi oleh benda asing. Benda asing ini dapat berupa bangkai binatang, bahan bangunan, ataupun disebabkan dari proses penguraian senyawa organik oleh bakteri (Yulianti, 2015). Hal ini dapat dideteksi melalui hidung manusia. Apabila air tersebut berbau lebih baik kita tidak meminumnya karena dapat membahayakan kesehatan tubuh. Air yang dikonsumsi manusia pada umumnya tidak berasa (tawar). Jika air tersebut memiliki rasa, itu menandakan bahwa air tersebut mengandung berbagai zat yang membahayakan tubuh dan tidak baik untuk dikonsumsi dalam tubuh. Hal tersebut menyatakan bahwa tidak semua air yang berasal dari alam ini dapat dikonsumsi manusia tanpa melalui proses filtrasi terlebih dahulu. Terdapat kemungkinan bahwa air yang ada di alam ini juga tercemar oleh bakteri atau zat-zat lainnya yang dapat membahayakan tubuh, sehingga akan lebih baik jika kita memasak air terlebih dahulu sebelum diminum agar dapat membunuh bakteri tersebut.

Ketersediaan air di muka Bumi ini sebenarnya tidak pernah berkurang. Namun, pada kenyataannya manusia hanya dapat mengkonsumsi air tersebut sekitar 5\% saja, sedangkan dengan tingginya tingkat modernisasi ini mampu menyebabkan penurunan angka kualitas air yang 5\% tadi, sehingga air yang dapat dikonsumsi juga berkurang dan semakin sedikit, hal inilah yang menyebabkan terjadinya krisis air (Sutandi, 2012). Adapun persoalan lain terkait dengan ketersediaan air bersih, yaitu tingkat pertumbuhan penduduk dalam suatu wilayah. Semakin banyak penduduk dalam suatu wilayah tersebut, maka akan semakin besar pula kebutuhan air bersih yang mereka butuhkan. Hal ini dapat berdampak negatif bagi kesehatan manusia, karena hampir 1,8 miliar manusia akan tinggal di suatu wilayah yang berpotensi mengalami kelangkaan air secara absolut (Sutandi, 2012).

Maka dengan ini, pemerintah menghimbau untuk membangun pusat-pusat atau sistem penyediaan air bersih yang nantinya bisa dikonsumsi sebagai air minum oleh manusia. Pengadaan air bersih untuk keperluan air minum pun harus memenuhi persyaratan yang sudah ditetapkan pemerintah dan Kemenkes. Air minum dikatakan aman bagi kesehatan apabila 
memenuhi persyaratan secara fisika, mikrobiologi, kimia, dan radioaktif (Wandrivel, 2012). Maka dari itu dibentuklah berbagai usaha depot air minum isi ulang yang nantinya akan mendistribusikan air minum isi ulang ini bagi para konsumen setelah melakukan uji mutu atau kualitas air di Laboratorium Pemeriksaan Kualitas Air.

Selain kualitas airnya yang harus terjaga, kondisi depot air minum tersebut juga harus terjaga dan steril dari pencemaran, baik debu ataupun hal lainnya yang berpotensi mengakibatkan pencemaran. Depot yang tidak berdiri sendiri dan bergabung dengan aktivitas lain sebanyak 44,4\%, memungkinkan terjadinya pencemaran dari lingkungan sekitar (Wandrivel, 2012). Depot air ini harus terjaga kebersihannya agar tidak terjadi kontaminasi dan tidak mengandung bakteri Coliform atau E.Coli, sehingga dapat menghasilkan kualitas air yang sesuai dengan persyaratan atau standar air minum (Wandrivel, 2012). Sebenarnya, kelompok bakteri ini tidak terlalu membahayakan bagi tubuh, tetapi dengan terdeteksinya bakteri-bakteri tersebut dapat menandakan bahwa air minum tersebut telah tercemar (Wandrivel, 2012). Hal ini juga menandakan bahwa air yang disajikan oleh depot tersebut memiliki kualitas yang buruk dan kurang baik untuk dikonsumsi dalam tubuh manusia. Selain itu, hal ini juga menandakan bahwa depot air tersebut tidak terjaga lingkungannya dari pencemaran yang ada.

\section{B. Manfaat Air Minum Bagi Kehidupan}

Air minum sangatlah berguna bagi kehidupan manusia terutama di bidang kesehatan. Tubuh manusia sangatlah memerlukan air untuk menjaga metabolisme dan fisiologi tubuh, sehingga air yang dijadikan air minum tersebut harus bersih dan tidak tercemar oleh apapun, baik bakteri maupun zat lainnya yang dapat membahayakan tubuh manusia. Manusia juga memerlukan air untuk membantu proses pelarutan zat-zat yang ada di dalam tubuhnya, karena sebagian besar zat-zat yang ada di dalam tubuh tersebut merupakan sebuah larutan dengan pelarut air (Maulana, 2018). Selain sebagai pelarut zat-zat pada tubuh, air minum juga sangat diperlukan bagi manusia untuk membentuk cairan kimia yang dibutuhkan dalam tubuh mereka. Dalam mengkonsumsi air minum, manusia memiliki takaran agar air yang mereka konsumsi dapat seimbang dengan air yang keluar dari tubuh mereka.

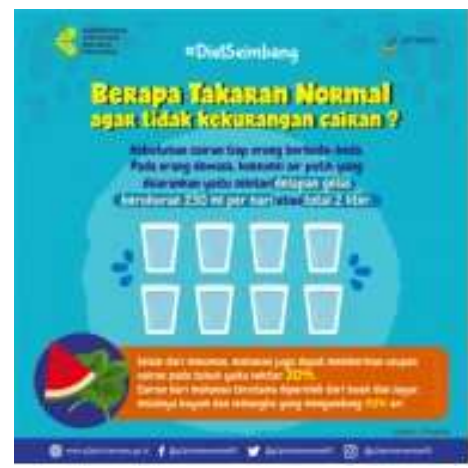

Gambar 2. Takaran normal air minum agar tidak kekurang cairan.

Sumber : Sites.google. Diakses melalui http://www.p2ptm.kemkes.go.id/infograpihcp2ptm/hipertensi-penyakit-jantung-dan-pembuluh-darah/page/14/berapa-takaran-normal-airagar-tidak-kekurangan-cairan-dalam-tubuh

Tubuh manusia membutuhkan air minum untuk dikonsumsi sebanyak 1 sampai 2,5 liter atau setara dengan 6-8 gelas setiap harinya (Sari, 2014). Hal ini ditujukan agar cairan yang keluar dari tubuh manusia dapat tergantikan dengan cairan yang masuk, sehingga terjadi keseimbangan dan tidak menyebabkan seseorang mengalami dehidrasi. Selain mengkonsumsi air minum, manusia juga diharuskan untuk mengkonsumsi makanan atau buah-buahan yang mengandung $90 \%$ air seperti buah pear, melon, dan semangka. Hampir sekitar $20 \%$ cairan dalam tubuh manusia berasal dari asupan makanan, sehingga manusia harus mengkonsumsi 
air dan makanan secara teratur dan seimbang agar tubuh juga dapat menerima energi dari makanan, karena selain membutuhkan cairan, tubuh juga membutuhkan zat-zat bergizi dari makanan untuk membantu petumbuhan serta memberi tenaga untuk melakukan kegiatan dalam kehidupan sehari-hari.

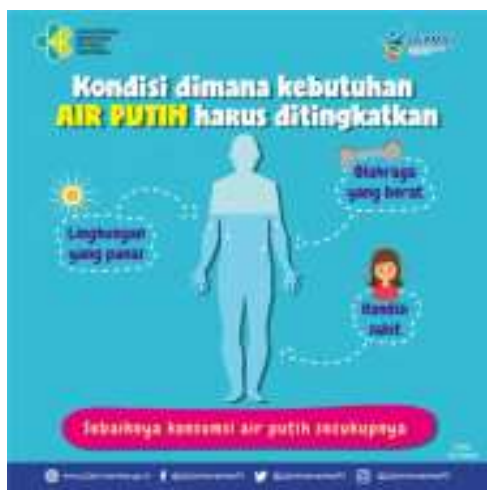

Gambar 3. Kondisi kebutuhan air putih harus ditingkatkan.

Sumber : Sites.google. Diakses melalui http://www.p2ptm.kemkes.go.id/infographicp2ptm/stroke/page/2/kondisi-dimana-kebutuhan-air-putih-harus-ditingkatkan

Kebutuhan air dalam tubuh manusia mampu bertambah dalam keadaan tertentu, misalnya dalam keadaan demam, latihan fisik, dan suhu lingkungan yang tinggi dimana manusia akan merasakan haus di hipotamulus (Mantarisa, 2011). Seseorang yang sedang berada di lingkungan yang dingin cenderung tidak membutuhkan air minum yang banyak dikarenakan mereka tidak merasa haus, sehingga mereka enggan mengkonsumsi air minum yang banyak. Pendapat seperti ini dikatakan salah apabila mereka hanya mengkonsumsi air minum ketika haus saja. Pada lingkungan yang dingin, manusia cenderung lebih banyak mengeluarkan cairan melalui urin dan pernapasan (Mantarisa, 2011), sehingga manusia dianjurkan untuk lebih banyak mengkonsumsi air minum walaupun mereka tidak merasa haus. Selain itu, mengkonsumsi air minum dapat membantu kita untuk menjaga kulit agar tidak menjadi kering (Mantarisa, 2011). Kebutuhan air seseorang juga akan meningkat ketika dalam kondisi demam, terutama peningkatan kebutuhan air dalam pernapasan. Hal ini menandakan bahwa manusia harus mengkonsumsi air minum tidak hanya ketika haus saja, manusia harus mengkonsumsi air minum setiap saat sesuai dengan takaran yang diberitahukan oleh Kemenkes agar tidak terjadi dehidrasi dan terkena gangguan penyakit lainnya.

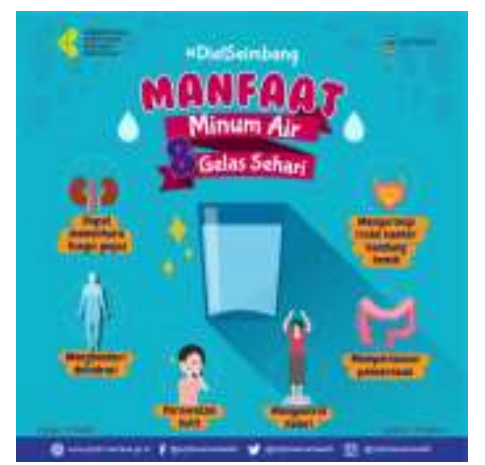

Gambar 4. Manfaat minum air.

Sumber : Sites.google. Diakses melalui http://p2ptm.kemkes.go.id/infographic-p2ptm/hipertensipenyakit-jantung-dan-pembuluh-darah/apa-saja-manfaat-minum-air-8-gelas-sehari

Manusia juga memerlukan air minum untuk membersihkan saluran makanan dari kotoran makanan yang tersisa. Jika manusia tidak mengkonsumsi air dengan teratur, ginjal 
akan sulit untuk bekerja dan akan menghasilkan urin yang berwarna pekat. Hal inilah yang mengakibatkan seseorang mengalami infeksi saluran kencing dan kencing batu. Selain itu, posisi seseorang ketika minum juga harus benar agar tidak terjadi kerusakan ginjal. Ketika minum seseorang dianjurkan untuk duduk agar ginjal dapat bekerja dan menyaring air dengan benar sesuai dengan ajaran Rasulullah SAW yang mengajarkan umatnya untuk duduk ketika makan dan minum. Namun pada kenyataannya, banyak manusia yang minum dengan posisi berdiri sehingga ginjal tidak dapat melakukan tugasnya dengan baik dan akhirnya terjadilah kerusakan ginjal. Selain menyebabkan kerusakan ginjal, minum dengan posisi berdiri juga dapat menyebabkan terjadinya gangguan pencernaan, hal ini terjadi akibat air yang masuk tidak tersaring terlebih dahulu oleh ginjal, karena itulah Rasullah SAW melarang umatnya untuk minum dengan posisi berdiri apalagi terburu-buru. Minum dengan posisi berdiri juga dapat mengacaukan keseimbangan cairan dalam tubuh yang dapat mempengaruhi daerahdaerah sendi pada tubuh seseorang.

Minum dengan posisi duduk dapat memberikan banyak manfaat seperti, memuaskan rasa dahaga atau haus yang dialami seseorang, mencegah air minum yang masuk langsung ke tenggorokan dan tidak tersaring oleh ginjal, membantu melancarkan sistem pencernaan, serta memberikan tubuh keseimbangan cairan yang dibutuhkan sesuai dengan kebutuhan tubuh manusia. Banyak sekali manfaat yang bisa didapatkan jika seseorang mau mengkonsumsi air minum secara teratur dan tidak hanya mengikuti rasa haus saja. Maka dari itu, sangat dianjurkan bagi manusia untuk mengkonsumsi air minum setiap saat dan dalam kondisi apapun, baik kondisi lingkungan yang panas maupun yang dingin sesuai dengan takarannya. Hal ini dilakukan agar tubuh manusia tidak pernah mengalami kekurangan cairan dan dapat terhindar dari berbagai macam penyakit.

\section{Memperkenalkan Manfaat Air Minum bagi Peserta Didik MI/SD melalui Pembelajaran Kurikulum 2013}

Pada umumnya, anak-anak lebih banyak bergerak dibandingkan dengan orang dewasa, sehingga banyak cairan yang dikeluarkan dari dalam tubuh mereka, baik melalui pernapasan, keringat, maupun urin. Hal ini dikarenakan pada masa ini anak-anak sedang asik bermain, sehingga mereka lebih banyak bergerak secara aktif dalam kegiatan sehari-hari. Pada umumnya usia anak-anak sekitar 6-12 tahun merupakan usia yang rentan terhadap gangguan fisik, seperti gangguan yang menyerang kesehatan tubuh anak-anak (Anna, 2018). Oleh karena itu, anak-anak harus mengkonsumsi air putih secara rutin agar tidak mengalami dehidrasi dan cairan yang keluar dari tubuh dapat tergantikan oleh cairan yang masuk. Namun, saat ini banyak sekali anak-anak yang tidak mau mengkonsumsi air putih dengan rutin, bahkan anak-anak lebih memilih mengkonsumsi minuman lain seperti susu, teh, sirup, dan minuman-minuman berwarna lainnya. Beberapa dari minuman yang dikonsumsi memang memiliki manfaat, contohnya seperti susu. Minuman ini sangat berguna untuk membantu pertumbuhan tubuh dan tulang dalam diri anak-anak. Namun, bukan berarti anak-anak harus sering-sering mengkonsumsi susu dibandingkan air putih. Anak-anak juga harus mengkonsumsi air putih secara teratur agar tubuh mereka sehat dan terhindar dari penyakitpenyakit fatal lainnya seperti, penyakit ginjal.

Seorang pendidik memiliki peranan penting untuk mengajarkan kepada peserta didik bagaimana pentingnya mengkonsumsi air putih. Pendidik harus memberikan contoh yang baik dan benar dalam mengkonsumsi air minum untuk menarik perhatian peserta didik agar mau mengkonsumsi air putih secara teratur dibandingkan mengkonsumsi minuman lainnya. Hal ini dilakukan agar tubuh mereka dapat menerima cairan yang cukup dan seimbang, sehingga mereka tidak akan mengalami dehidrasi atau kekurangan cairan. Dalam pembelajaran kurikulum 2013, mata pelajaran pada tingkat MI/SD menggunakan model broad fields curriculum, dimana dalam model ini kurikulum menggabungkan beberapa mata pelajaran 
yang berkaitan menjadi bidang studi berupa tematik. Pembelajaran tematik ini terdiri dari beberapa mata pelajaran seperti, Bahasa Indonesia, Matematika, IPA, Kewarganegaraan, dan beberapa mata pelajaran lainnya. Namun dalam pembelajaran tematik, pembahasan yang diberikan biasanya tidak terlalu mendalam, sehingga anak-anak tidak menerima pengetahuan secara luas. Pendidik dapat menyisipkan beberapa pengetahuan ketika proses pembelajaran tersebut terjadi agar anak-anak dapat menerima pengetahuan yang lebih luas melalui pendekatan saintifik sesuai dengan kurikulum 2013 (Harahap, 2018). Dalam sub-bab yang membahas materi terkait dengan kesehatan, pendidik dapat menyisipkan pengetahuan kepada peserta didik terkait dengan manfaat dari mengkonsumsi air putih secara teratur.

Dalam Kemendikbud terdapat 18 karakter yang dapat diajarkan kepada anak-anak melalui pendidikan di sekolah. Pendidikan ini disebut dengan pendidikan karakter, dimana anak-anak mempelajari nilai-nilai karakter yang meliputi komponen pengetahuan, kesadaran atau kemauan, dan tindakan untuk melaksanakan nilai-nilai tersebut, baik terhadap Tuhan Yang Maha Esa, diri sendiri, sesama manusia, lingkungan, maupun kebangsaan (Putry, 2018). Pendidikan karakter ini bertujuan untuk mengembangkan nilai-nilai yang membentuk karakter meliputi, mengembangkan potensi peserta didik agar menjadi manusia berhati baik, berpikiran baik, dan berperilaku baik (Hartono, 2014).

Dalam hal ini, pendidik dapat memanfaatkan salah satu karakter Kemendikbud tersebut untuk memperkenalkan manfaat air minum kepada peserta didik, terutama pada tingkat MI/SD melalui pendidikan karakter dalam proses pembelajaran di kelas. Salah satu karakter yang sesuai untuk memperkenalkan manfaat air minum kepada peserta didik ialah karakter tanggung jawab. Tanggung jawab merupakan sikap dan perilaku seseorang untuk melaksanakan tugas dan kewajibannya yang seharusnya dilakukan, baik terhadap diri sendiri, masyarakat, lingkungan (alam, sosial, dan budaya), negara dan Tuhan Yang Maha Esa. Karakter ini mengajarkan peserta didik untuk memiliki rasa tanggung jawab dalam melaksanakan kewajibannya untuk menjaga kesehatan diri anak-anak. Melalui karakter ini, pendidik dapat memperkenalkan bagaimana manfaat air minum kepada peserta didik melalui 2 pendekatan yaitu, pendekatan intervensi dan pendekatan habituasi. Pendekatan intervensi dikembangkan melalui suasana interaksi belajar mengajar dan proses pembelajaran yang sengaja dirancang untuk mencapai tujuan pembentukan karakter dengan program kegiatan yang terstruktur (Hartono, 2014).

Pendekatan habituasi dilakukan dengan menciptakan kondisi yang kondusif yang memungkinkan peserta didik mampu menguatkan karakter ini, baik di sekolah, rumah, maupun di lingkungan masyarakatnya yang membiasakan diri berperilaku yang baik seperti yang telah di praktikkan melalui proses intervensi (Hartono, 2014). Dalam pendekatan ini, pendidik diharapkan mampu bekerja sama dengan orangtua peserta didik untuk membantu menguatkan pendidikan karakter tersebut di rumah, terutama karakter bertanggung jawab. Melalui penerapan karakter bertanggung jawab ini, anak-anak akan lebih memperhatikan kesehatan diri masing-masing, sehingga ketika guru memperkenalkan manfaat air minum bagi kesehatan, peserta didik akan tertarik untuk menerapkannya. Selain itu, pendidik juga dapat meminta bantuan kepada orangtua untuk memperkenalkan manfaat air minum kepada anakanaknya melalui karakter bertanggung jawab yang telah diajarkan baik di rumah maupun di sekolah, sehingga anak-anak paham dengan baik dan benar bahwa air minum itu memiliki manfaat yang banyak, terutama bagi kesehatan tubuh.

Anak-anak juga akan mengetahui bahwa tanpa mengkonsumsi air putih secara teratur, tubuh akan kekurangan cairan yang membuat seseorang mengalami dehidrasi. Selain itu, seseorang juga mudah terserang oleh penyakit-penyakit lain seperti penyakit ginjal dan lainlain apabila tidak mengkonsumsi air putih secara teratur. Oleh karena itu, pendidik harus menerapkan karakter bertanggung jawab yang benar dan matang pada diri peserta didik melalui pendidikan karakter di sekolah, agar peserta didik mau mengkonsumsi air putih secara 
teratur demi menjaga kesehatan diri masing-masing. Pendidik dapat menerapkan karakter bertanggung jawab ini melalui pengetahuan serta pengalaman pribadinya yang bisa menjadi contoh untuk menerapkan karakter tersebut. Setelah pendidik mampu menerapkan karakter bertanggung jawab pada peserta didik dengan baik, maka pendidik dapat mulai memperkenalkan manfaat mengkonsumi air putih secara teratur melalui proses pembelajaran di dalam kelas. Selain memperkenalkan manfaat mengkonsumsi air putih tersebut, pendidik juga dapat menyediakan fasilitas air minum di dalam kelas, seperti menyediakan air minum isi ulang. Hal ini ditujukan agar anak-anak mau mengkonsumsi air putih secara teratur dibandingkan mengkonsumsi minuman-minuman lainnya yang dapat mengganggu kesehatan. Selain itu, pembelajaran dan penerapan pendidikan karakter bertanggungjawab ini juga ditujukan agar peserta didik mampu menjalankan kewajibannya dalam menjaga kesehatan diri masing-masing dengan mengkonsumsi air putih secara teratur sesuai dengan anjuran yang telah diberikan Kemenkes dan disampaikan oleh guru.

\section{PENUTUP}

Berdasarkan uraian pembahasan diatas, dapat disimpulkan bahwa banyak sekali manfaat yang didapatkan dari mengkonsumsi air minum secara teratur terutama bagi anak-anak pada tingkat pendidikan dasar. Anak-anak yang mengkonsumsi air minum secara teratur akan terhindar dari berbagai penyakit-penyakit fatal yaitu, penyakit ginjal, kencing batu, gangguan pencernaan, dan lain-lain. Hal ini dikarenakan pada usia 6-12 tahun, anak-anak mudah terserang penyakit, sehingga anak-anak sangat dianjurkan untuk mengkonsumsi air minum setiap saat. Dalam hal ini, peran orangtua dan pendidik sangatlah penting untuk memperkenalkan manfaat dari mengkonsumsi air minum terutama air putih secara teratur guna menjaga kesehatan tubuh anak-anak. Pendidik dapat memperkenalkan manfaat dari mengkonsumi air minum melalui pembelajaran Kurikulum 2013 dengan pendidikan karakter yang dilakukan di dalam kelas. Salah satu pendidikan karakter yang tepat untuk menyampaikan manfaat mengkonsumsi air putih tersebut ialah karakter bertanggung jawab. Dengan menerapkan karakter ini, anak-anak akan merasa memiliki kewajiban untuk menjaga kesehatan diri mereka masing-masing, sehingga ketika guru memberitahukan apa saja manfaat mengkonsumsi air putih secara teratur bagi kesehatan, anak-anak akan mulai mengkonsumsi air putih tersebut secara teratur guna menjaga kesehatan diri masing-masing agar terhindar dari berbagai macam penyakit.

\section{DAFTAR PUSTAKA}

Anna. (2018). Manajemen Kesehatan Peserta Didik Sekolah Dasar. Jurnal Administrasi Pendidikan, 25(1), 65.

Dewi Hastuti, Y., Nasution, E., \& Aritonang, E. (2015). Perilaku Konsumsi Air Minum Pada Siswa/Siswi SMA Negeri 3 Medan Tahun 2015 (Drinking of Water Consumption Behavior of Students in SMA Negeri 3 Medan 2015). Jurnal USU, 1(3).

Harahap, A. (2018). Implementasi Nilai-nilai Karakter dalam Pembelajaran Tematik Kelas III SDIT Darul Hasan Padangsidimpuan. Jurnal Abdau: Jurnal Pendidikan Madrasah Ibtidaiyah, 1(1).

Harahap, N. (2014). Penelitian Kepustakaan. Jurnal Iqra', 8(1).

Hartono. (2014). Pendidikan Karakter dalam Kurikulum 2013. Jnana Budaya, 19(2), 259268.

Mantarisa, R. G. (2011). Analisis Pola Konsumsi dan Kecukupan Air Pada Siswa Sekolah Dasar Negeri Empang 1 Bogor. In Institut Pertanian Bogor. http://repository.ipb.ac.id/jspui/bitstream/123456789/53499/10/I11rgm.pdf

Maulana, E. S. (2018). Gambaran Sikap Siswa/Siswi Jurusan Keperawatan dalam Mengkonsumsi Air Putih di SMK Muhammadiyah 4 Samarinda Karya Tulis Ilmiah. In 
Universitas

Muhammadiyah

Kalimantan

Timur.

https://dspace.umkt.ac.id/bitstream/handle/463.2017/598/evi sylvia maulana .pdf? sequence $=1 \&$ isAllowed $=\mathrm{y}$

Mirza, M. N. (2014). Hygiene Sanitasi dan Jumlah Coliform Air Minum Hygiene Sanitation and Total Coliform of Drinking Water. KEMAS, 9(2), 167-173.

Mirzaqon, A., \& Purwoko, B. (2017). Studi Kepustakaan mengani Landasan Teori dan Praktik Konseling Expressive Writing Library Research of The Basic Theory and Practice of Expressive Writing Counseling. Jurnal BK UNESA, 8(1). https://media.neliti.com/media/publications/253525-studi-kepustakaan-mengenailandasan-teor-c084d5fa.pdf

Putri, A. E. (2019). Evaluasi Program Bimbingan dan Konseling: Sebuah Studi Pustaka. In Jurnal Bimbingan Konseling Indonesia (Vol. 4, Issue 2).

Putry, R. (2018). Nilai Pendidikan Karakter Anak di Sekolah Perspektif Kemendiknas. Gender Equality: Journal of Child and Gender Studies, 4(1).

Ranteallo, R. R. (2015). Hubungan Tingkat Pengetahuan dan Sikap Siswa Tentang Manfaat Air Putih Dengan Perilaku Mengkonsumsi Air Putih Pada Siswa SMP Katolik Makale Kabupaten Tana Toraja Tahun 2014. Jurnal AgroSainT, 6(3), 213-219.

Sari, P. (2014). Tingkat Pengetahuan Tentang Pentingnya Mengkonsumsi Air Mineral Pada Siswa Kelas IV di SD Negeri Keputaran A Yogyakarta. Jurnal Pendidikan Jasmani Indonesia, 10(2).

Supriyadi. (2016). Community Of Practitioners : Solusi Alternatif Berbagi Pengetahuan Antar Pustakawan. Lentera Pustaka, 2(2), 83-93.

Sutandi, M. C. (2012). Penelitian Air Bersih di PT. Summit Plast Cikarang. Jurnal Teknik Sipil, 8(2), 76-141.

Wandrivel, E. a. (2012). Kualitas Air Minum Yang Diproduksi Depot Air Minum Isi. In Jurnal Kesehatan Andalas (Vol. 1, Issue 3).

Yulianti, A. (2015). Prototype Alat Pengolahan Air Laut Menjadi Air Minum (Pengaruh Variasi Packing Filter Terhadap Kualitas Air dengan Analisis DO, Salinitas, dan Konduktivitas. In Politeknik Negeri Sriwijaya. http://eprints.polsri.ac.id/1954/3/Bab 2.pdf 